\title{
Pengaruh Profitabilitas dan Kualitas Pengungkapan Corporate Social Responsibility terhadap Harga Saham
}

\author{
TRIANI \\ SITI NUR AMI'IN \\ Jurusan Akuntansi, Sekolah Tinggi Ilmu Ekonomi Widya Manggala \\ Jalan Sriwijaya No. 32 \& 36 Semarang 50242 \\ Email : triani129@gmail.com
}

Diterima 15 Mei 2019; disetujui 29 Mei 2019

\begin{abstract}
This study aims to determine the effect of Earning Per Share (EPS), Return On Equity (ROE) and Quality of CSR on LQ 45 Company Stock Prices on the Indonesia Stock Exchange in 2015-2017. The population of this study was 45 companies and the sample was $36 L Q 45$ companies listed on the Indonesia Stock Exchange for the period 2015-2017. The method of analysis uses classical assumption test calculations and analysis tools using multiple linear regression with SPSS software. Partial results show that Earning Per Share (X1) and Return On Equity (X2) have a significant influence on stock prices, while the quality of CSR (X3) does not affect stock prices. Simultaneously test all Earning Per Share (EPS), Return On Equity (ROE) and Quality of CSR have an effect on the Stock Price of LQ 45 companies listed on the Indonesia Stock Exchange in 2015-2017.
\end{abstract}

Keywords: Earning Per Share (EPS), Return On Equity (ROE), CSR Quality, Stock Price

\section{PENDAHULUAN}

Latar Belakang. Salah sat tujuan utama perusahaan adalah memaksimalkan kekayaan pemegang saham, yang dapat diukur dengan harga saham biasa perusahaan. Harga saham perusahaan dipengaruhi oleh faktor-faktor internal dan eksternal. Faktor internal berasal dari dalam perusahaan seperti laba per lembar saham (Earning per Sharel EPS), tingkat bunga, jumlah kas dividen yang diberikan, jumlah laba yang didapat perusahaan, tingkat risiko dan pengembalian, dan strategi pemasaran (Weston dan Brigham. 2001).

Faktor internal yang mempengaruhi harga saham berdasarkan Muammarsyah, (2012) menyatakan semakin baik kinerja suatu perusahaan maka semakin kecil kemungkinan risiko investasi yang akan ditanggung investor dan semakin besar kemungkinan return yang akan diperoleh, ini akan mengakibatkan semakin banyak investor akan berinvestasi pada saham perusahaan tersebut. Rasio keuangan terdiri dari: (1) rasio likuiditas; (2) rasio aktivitas; (3) rasio profitabilitas; (4) rasio solvabilitas (leverage); dan (5) rasio pasar/penilaian. Dari kelima rasio keuangan tersebut, rasio profitabilitas merupakan rasio keuangan yang sering dipakai peneliti untuk dijadikan sebagai informasi dalam penelitian yang berkaitan dengan dampak atau pengaruh yang diberikan terhadap earnings per share perusahaan. Muammarsyah, (2012). Rasio profitabilitas merupakan salah satu cara untuk menilai secara tepat dan sejauh mana tingkat pengembalian yang akan didapat dari aktivitas investasinya. Jika kondisi perusahaan dikategorikan menguntungkan atau menjanjikan keuntungan di masa mendatang maka banyak investor yang akan 
menanamkan dananya untuk membeli saham tersebut. Hal tersebut tentu saja mendorong harga saham naik menjadi lebih tinggi.

Selain faktor internal, harga saham juga dipengaruhi Faktor eksternal menurut Weston dan Brigham (2009) diantaranya tingkat kegiatan perekonomian pada umumnya dan keadaan bursa saham. Sedangkan menurut Alwi (2003) faktor yang memengaruhi harga saham berkaitan dengan pengumuman-pengumuman yang dibuat perusahaan, baik itu berupa pengumuman kebijakan finansial perusahaan, kegiatan operasi perusahaan, maupun pengumuman mengenai pengungkapan informasi sosial perusahaan.

Informasi dalam laporan keuangan dapat mempengaruhi kenaikan dan penurunan harga saham di pasar modal, serta menandai kemarakan dan kelesuan para pelaku pasar modal, perubahan harga saham salah satunya merupakan reaksi investor terhadap informasi, baik informasi yang berkaitan dengan ekonomi dan yang terlebih lagi informasi sosial dan lingkungan yang berkaitan dengan politik atau kondisi suatu negara (Susana, 2007).

Saat ini investor tidak hanya menuntut perusahaan untuk meningkatkan performanya dalam pemebagian deviden yang besar, sehingga menyebabkan perusahaan mengabaikan tanggung jawab sosialnya. Namun saat ini investor dan calon lebih menyukai citra perusahaan yang memiliki kepedulian terhadap sosial dan lingkungan. Hal ini dikarenakan perusahaan yang mengabaikan dampak sosial dan lingkungan akan memiliki dapak negatif dan memiliki resiko tinggi bagi perusahaan dikemudian hari. Kusumadilaga (2010) mengatakan bahwa masyarakat saat ini cenderung cerdas dalam memilih produk, mereka cenderung lebih memilih produk yang dihasilkan oleh perusahaan yang peduli terhadap lingkungan dan melaksanakan Corporate Social Responsibility.

Berdasarkan uraian tersebut, pengungkapan Corporate Social Responsibility (CSR) menjadi alat bagi perusahaan selain sebagai bentuk pertanggung jawaban sosial akan tetapi sebagai alat untuk meningkatkan citra produk perusahaan. Dalam penelitian ini, tidak hanya melihat indeks pengungkapan CSR semata, namun lebih melihat dari sisi kualitas pengungkapan CSR. Tingkat Pengungkapan CSR tersebut dilihat dari kualitas informasi [CSDQ] merupakan proses analisis isi yang mengubah informasi kualitatif dari laporan tahunan menjadi nilai (kuantitatif). Sehingga, hanya informasi relevan yang memiliki kesamaan makna dan memberikan gambaran keberlanjutan pada setiap item CSD yang akan mendapat nilai.

Pengaruh pengungkapan CSR yang berpengaruh terhadap harga saham didukung oleh beberapa penelitian terdahulu. Tiap tahun perusahaan meningkatkan pengungkapan informasi Corporate Social Responsibility dalam laporan tahunannya (Gray, dkk 1995). Studi yang dilakukan Basalamah dan Jermias (2005) dan De Klerk, dkk (2015) menunjukkan bahwa salah satu alasan manajemen melakukan pelaporan Corporate Social Responsibility adalah untuk alasan strategis. Ini menyatakan bahwa salah satu pendekatan yang digunakan dalam melaksanakan pelaporan Corporate Social Responsibility adalah pendekatan motif(Sembiring, 2003). Hal tersebut berarti perusahaan melakukan pelaporan Corporate Social Responsibility berawal dari harapan perusahaan untuk memperoleh umpan balik, terutama ekonomi (seperti dapat mempengaruhi harga saham).

Berdasarkan latar belakang di atas, peneliti tertarik untuk meneliti pengaruh profitabilitas dan pengungkapan CSR terhadap harga saham pada perusahaan LQ45. LQ45 atau Liquid 45 Bursa Efek Indonesia ialah gabungan dari 45 perusahaan unggulan yang sahamnya merupakan favorite investor. Saham-saham tersebut menjadifavorite investor karena dinilai memiliki risiko yang lebih rendah dibandingkan saham yang lainnya. Indeks LQ45 merupakan salah satu indeks harga saham yang terdapat di Bursa Efek Indonesia, dan merupakan salah satu indeks yang terkenal selain dari Indeks Harga Saham Gabungan (IHSG).

Tujuan Penelitian. Tujuan penelitian ini adalah untuk menganalisis pengaruh profitabilitas dan kualitas pengungkapan CSR terhadap Harga Saham Perusahaan LQ 45 yang terdaftar di BEI periode 2015-2017

\section{TINJAUAN PUSTAKA}

Harga Saham. Saham adalah surat bukti atau tanda penyertaan modal pada suatu perseroan terbatas (Martono dan Harjito, 2005). Sedangkan 
menurut Eduardus Tandelilin (2001) pengertian saham adalah surat bukti bahwa kepemilikan atas aset-aset perusahaan yang menerbitkan saham, dengan memiliki saham suatu perusahaan, maka investor akan mempunyai hak terhadap pendapatan dan kekayaan perusahaan, setelah dikurangi dengan pembayaran semua kewajiban.

Profitabilitas. Rasio profitabilitas merupakan salah satu cara untuk menilai secara tepat dan sejauh mana tingkat pengembalian yang akan didapat dari aktivitas investasinya. Jika kondisi perusahaan dikategorikan menguntungkan atau menjanjikan keuntungan di masa mendatang maka banyak investor yang akan menanamkan dananya untuk membeli saham tersebut. Hal tersebut tentu saja mendorong harga saham naik menjadi lebih tinggi.

Profitabilitas adalah rasio yang berusaha mengukur kemampuan perusahaan untuk menghasilkan laba, baik dengan menggunakan seluruh aktiva yang ada maupun dengan menggunakan modal sendiri (Moeljadi, 2006). Menurut Kasmir (2008:196) rasio profitabilitas merupakan rasio untuk menilai kemampuan perusahaan dalam mencari keuntungan. Rasio ini menunjukkan efektifitas dan efisiensi perusahaan, menurut Werner R. Murhadi (2013) mengemukakan bahwa rasio profitabilitas menggambarkan kemampuan perusahaan untuk menghasilkan keuntungan dari penjualan dan pendapatan investasi yang ditunjukkan dalam laporan rugi/laba. Rasio profitabilitas yang dijadikan proksi dalam penelitian ini adalah Return On Equity (ROE) dan Earning Per Share (EPS).

Return On Equity (ROE) mengukur kemampuan perusahaan memperoleh laba yang tersedia bagi pemegang saham perusahaan atau untuk mengetahui besarnya kembalian yang diberikan oleh perusahaan untuk setiap rupiah modal dari pemilik (Kasmir, 2013). Rasio ini menunjukkan efisiensi penggunaan modal sendiri. Semakin tinggi rasio ini maka semakin baik, sehingga dapat diartikan posisi perusahaan semakin kuat.

Earning Per Share (EPS) merupakan ukuran kemampuan perusahaan untuk menghasilkan keuntungan per lembar saham pemilik. EPS menggambarkan profitabilitas perusahaan yang tergambar pada setiap lembar saham. Semakin tinggi EPS, berarti performance perusahaan semakin baik dalam menghasilkan keuntungan bersih setiap lembar sahamnya, sehingga saham pun akan diamati oleh para investor dan harga jualnya akan naik (Kasmir, 2013).

Teori Stakeholder. Teori stakeholder menjelaskan bahwa perusahaan bukanlah sebuah entitas yang hanya beroperasi untuk kepentingan sendiri namun harus memberikan manfaat bagi stakeholdernya (pemegang saham, keditor, konsumen, supplier, pemerintah, masyarakat sekitar perusahaan, analisis dan pihak lain). Dengan demikian, keberadaan suatu perusahaan sangat dipengaruhi oleh dukungan yang diberikan oleh stakeholder kepada perusahaan tersebut (Ghozali dan Chariri, 2007). Pengugkapan CSR perusahaan dalam laporan tahunan dapat meningkatkat kelangsungan hidup perusahaan yang nantinya akan meningkatkan kepuasan dari stakeholder itu sendiri. Keberlangsungan hidup perusahaan salah satunya ditandai semakin banyaknya konsumen yang loyal. Meningkatkan loyalitas konsumen akan meningkatkan penjualan perusahaan dan tentunya juga akan berdapampak pada peningkatan harga saham.

Teori Sinyal. Teori sinyal diartikan sebagai motivasi perusahaan untuk mengungkapakan informasi kinerja sosial dan lingkungan kepada pihal eksternal yang dituangkan dalam lapaoran tahuan. Tujuannya agar para stakholder dapat melihat sinyal positif dari informasi yang disampaiakn perusahaan terkait Transparansi kinerja sosial dan lingkungan yang diungkapkan perusahaan membuat laporan keuangan yang diterbitkan perusahaan semakin dapat diandalkan, sehingga akan memberikan respon positif bagi keputusan investasi pembelian saham pada perusahaan tersebut. Menurut teori signal (signaling theory) membuat manajer akan menyampaikan informasi positif kepada investor agar saham perusahaan meningkat (Sugiarto, 2009:38).

Hipotesis. Berdasarkan tinjauan teori di atas, maka hipotesis yang akan diajukan dalam penelitian ini antara lain:

H1 : EPS berpengaruh positif terhadap harga saham

H2 : ROE berpengaruh positif terhadap harga saham

H3 : CSRDQ berpengaruh terhadap harga saham 


\section{METODE PENELITIAN}

Desain Penelitian. Penelitian ini termasuk dalam penelitian kuantitatif. Penelitian kuantitatif adalah penelitian yang analisisnya menekankan data berupa angka-angka yang diolah dengan metode statistika (Fauzi, 2009). Penelitian ini pada dasarnya dilakukan untuk pengujian hipotesis (penelitian inferensial) yang hasil kesimpulannya pada suatu probabilitas kesalahan penolakan hipotesis nihil.

Populasi dan Sampel Penelitian. Adapun yang menjadi populasi dalam penelitian ini adalah seluruh perusahaan LQ 45 yang terdaftar di Bursa Efek Indonesia (BEI) periode 2015-2017 secara berturut-turut sebanyak 36 perusahaan. Sampel dalam penelitian ini menggunakan seluruh populasi, yaitu 36 perusahaan LQ 45 yang terdaftar di BEI secara berturut-turut dari 2015-2017 atau 108 data.

Variabel dan Indikator. Penelitian ini menggunakan Harga Saham sebagai variabel dependen yang diukur dengan harga penutupan saham (closing price) tiap perusahaan yang diperoleh dari harga saham pada periode akhir tahun. Dalam penelitian ini harga yang di gunakan adalah Harga Saham Pada Perusahaan LQ45 Di Bursa Efek Indonesia Tahun 2015-2017. Sedangkan variabel independen dalam penelitian ini terdiri dari profitabilitas dan kualitas pengung-kapan CSR.

Profitabilitas diukur dengan Earning per Share (EPS) dan Return on Equity (ROE) EPS merupakan ukuran kemampuan perusahaan untuk menghasilkan keuntungan per lembar saham pemilik. Sedangkan ROE adalah kemampuan perusahaan memperoleh laba yang tersedia bagi pemegang saham perusahaan atau untuk mengetahui besarnya kembalian yang diberikan oleh perusahaan untuk setiap rupiah modal dari pemilik.

Kualitas pengungkapan CSR (CSRDQ) merupakan proses analisis isi yang mengubah informasi kualitatif dari laporan tahunan menjadi nilai (kuantitatif). Sehingga, hanya informasi relevan yang memiliki kesamaan makna dan memberikan gambaran keberlanjutan pada setiap item CSR yang akan mendapat nilai. Bobot nilai untuk kualitas dapat dirangkum dalam tabel 1 .

Teknik Analisis. Dalam penelitian ini teknik yang digunakan untuk menganalisis data adalah analisis regresi linier berganda.

\section{HASIL DAN PEMBAHASAN}

Hasil Analisis Regresi Linier Berganda. Hasil analisis regresi linier berganda secara singkat ditampilkan dalam tabel 2.

Output tersebut merupakan hasil koreksi dengan metode Durbin's two-step untuk mengoreksi masalah autokorelasi. Hasil tersebut, nantinya langsung dapat digunakan dalam laporan penelitian. Hasil metode Durbin's two-step terdapat beberapa perbedaan dalam nilai standard error maupun nilait dan nilai sig. Hasil koreksi Durbin's two-step lebih valid dibandingkan hasil OLS tanpa koreksi yang menyebabkan kesalahan pengambilan keputusan. Setelah melakukan pengobatan dengan Durbin's two-step Method nilai DW sebesar 2,193 yang menunjukkan bahwa $\mathrm{dl}<\mathrm{DW}<4$ $\mathrm{du}(1,613<2,193<2,264)$ jadi tidak berkorelasi positif maupun negatif.

Berdasarkan hasil analisis regresi di atas maka dapat dibuat sebuah rumus regresi sebagai berikut:

Tabel 1

\section{Pengukuran Kualitas Pengungkapan CSR}

\begin{tabular}{|c|c|c|}
\hline & $\begin{array}{c}\text { Kualitas Pengungkapan } \\
\text { (Bagaimana Pengukurannya) }\end{array}$ & Definisi Kualitas \\
\hline 0 & $=$ tidak diungkapkan & Tidak mengungkapkan informasi \\
\hline 1 & $=$ diungkapkan sebagian & Mengungkapkan informasi yang tidak lengkap \\
\hline 2 & $\begin{array}{l}=\text { diungkapkan lengkap hanya } \\
\text { naratif }\end{array}$ & $\begin{array}{l}\text { Mengugkapkan informasi lengkap tapi hanya penggambaran } \\
\text { dalam bentuk prosa (uraian) }\end{array}$ \\
\hline 3 & $\begin{array}{l}=\text { diungkapkan lengkapsecara } \\
\text { naratif dan kuantitatif }\end{array}$ & $\begin{array}{l}\text { Mengugkapkan informasi lengkap dengan penggambaran dalam } \\
\text { bentuk prosa serta dilengkapi dengan pengungkapan berupa } \\
\text { data angka (moneter dan non moneter) }\end{array}$ \\
\hline
\end{tabular}

Sumber: Laskar \& Gopal Maji (2016) 
$\mathrm{Y}=-2669,90+16,571 \mathrm{EPS}+12.018,758 \mathrm{ROE}$ - 950,339 CSRD, di mana:

1. Konstanta ( $\left.\boldsymbol{\beta}_{\mathbf{0}}\right)$ sebesar $-2669,290$ menyatakan bahwa jika semua variabel bebas $\left(X_{1}\right.$ sampai $\mathrm{X}_{3}$ ) dianggap konstan maka rata-rata harga saham (Y) sebesar -2669,290.

2. Nilai koefisien regresi $\left(\boldsymbol{\beta}_{1}\right)$ variabelEPS $\left(X_{1}\right)$ sebesar 16,571 memiliki arti apabila EPS naik $1 \%$, maka harga saham (Y) naik sebesar 16,571 dengan asumsi variabel lainnya konstan

3. Nilai koefisien regresi $\left(\boldsymbol{\beta}_{2}\right)$ variabel $\operatorname{ROE}\left(\mathrm{X}_{2}\right)$ sebesar 12.018,758 memiliki arti apabila ROE naik $1 \%$, maka harga saham (Y) naik sebesar $12.018,758$ dengan asumsi variabel lainnya konstan.

4. Nilai koefisien regresi $\left(\boldsymbol{\beta}_{\mathbf{3}}\right)$ variabel kualitas CSR $\left(X_{3}\right)$ sebesar $-950,339$ memiliki arti apabila kualitas pengungkapan CSR naik sebesar 1\%, maka harga saham akan turun sebesar 950,339 dengan asumsi variabel lainnya konstan.

Koefisien Determinasi. Koefisien determinasi yang diukur dengan nilai Adjusted $\mathrm{R}^{2}$ merupakan nilai untuk mengevaluasi model regresi mana yang terbaik atau melihat seberapa besar kemampuan variabel bebas (X) dalam menjelaskan variabel terikat (Y). Nilai Adjusted $\mathrm{R}^{2}$ sebesar 0,874 . artinya variabel $\mathrm{X}$ mampu menjelaskan variabel Y sebesar $87,4 \%$ sedangkan sisanya $12,6 \%$ dijelaskan oleh variabel lain di luar model penelitian ini.

Uji Hipotesis. Uji secara individual / parsial / uji t digunakan untuk menunjukkan seberapa jauh pengaruh tiap-tiap variabel independen dalam menerangkan variabel dependen. Berdasarkan tabel di atas, dilihat dari nilai sig tiap-tiap variabel maka dapat dianalisis variabel EPS (X1) dan variabel $\mathrm{ROE}(\mathrm{X} 2)$ berpengaruh terhadap variabel harga saham (Y). Nilai sig variabel tersebut lebih kecil dari 0,05. Sedangkan untuk variabel lainnya seperti variabel kualitas CSR (X3), tidak berpengaruh terhadap variabel kualitas CSR (Y). Hal tersebut, dapat terlihat dari nilai sig yang lebih besar dari 0,05.

Pembahasan Pengaruh EPS terhadap Harga Saham. Hasil pengujian menyatakan bahwa EPS berpengaruh terhadap harga saham, sehingga hipotesis H1 diterima. Penelitian ini mendukung penelitian yang dilakukan Nurfadillah (2011) yang menyimpulkan bahwa Earning per Share memiliki pengaruh positif terhadap harga saham.

Earning per share atau laba per lembar saham menunjukkan besarnya laba bersih perusahaan yang siap dibagikan bagi semua pemegang saham perusahaan atau jumlah uang yang dihasilkan (return) dari setiap lembar saham. Semakin tinggi EPS, berarti performance perusahaan semakin baik dalam menghasilkan keuntungan bersih setiap lembar sahamnya, sehingga saham pun akan diamati oleh para investor dan harga jualnya akan naik (Kasmir, 2013).

Bagi para investor, informasiEPS merupakan informasiyang paling mendasar dan berguna, karena bisa menggambarkan prospek earning perusahaan di masa depan (Tandelilin, 2001). Selain itu menurut Alwi (2003) Earning per Share biasanya menjadi perhatian pemegang saham pada umumnya atau calon pemegang saham dan manajemen. Semakin tinggi EPS suatu perusahaan berarti semakin besar earning yang akan di terima investor dari investasinya tersebut, sehingga bagi perusahaan peningkatan EPS akan berdampak positif pada harga saham di pasar.

Tabel 2

Hasil Analisis Regresi Linier Berganda

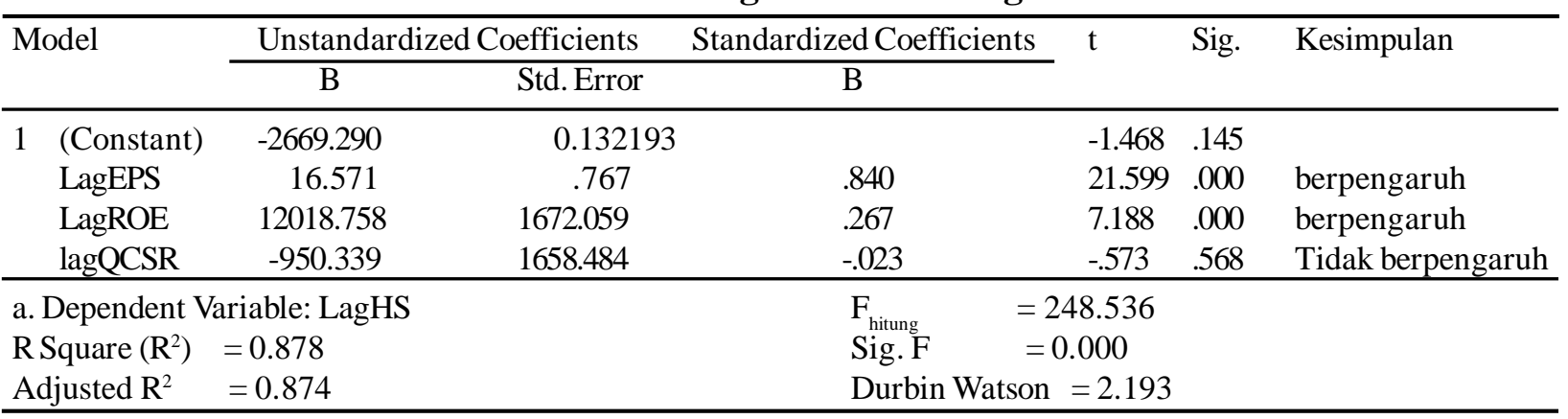

Sumber: hasil olahan SPSS, 2019 
Pembahasan Pengaruh ROE terhadap Harga Saham. Hasil pengujian menyatakan bahwa ROE berpengaruh terhadap harga saham, sehingga $\mathrm{H} 2$ diterima. Hasil penelitian ini didukung oleh penelitian yang dilakukan oleh Nurfadillah (2011) yang menyimpulkan bahwa Return On Equity memiliki pengaruh positif terhadap harga saham. Selajutnya juga mendukut teori yang dikemukakan oleh Kasmir, (2013) yang menyatakan bahwa Return On Equity (ROE) mengukur kemampuan perusahaan memperoleh laba yang tersedia bagi pemegang saham perusahaan atau untuk mengetahui besarnya kembalian yang diberikan oleh perusahaan untuk setiap rupiah modal dari pemilik. Rasio ini menunjukkan efisiensi penggunaan modal sendiri. Semakin tinggi rasio ini maka semakin baik, sehingga dapat diartikan posisi perusahaan semakin kuat.

Return On Equity menunjukkan keuntungan yang akan dinikmati oleh pemilik saham. Adanya pertumbuhan ROE menunjukkan prospek perusahaan yang semakin baik karena berarti adanya potensi peningkatan keuntungan yang diperoleh perusahaan, sehingga akan meningkatkan kepercayaan investor serta akan mempermudah manajemen perusahaan untuk menarik modal dalam bentuk saham. Rasio ini berguna untuk mengetahui efisiensi manajemen dalam menjalankan modalnya, semakin tinggi ROE berarti semakin efisien dan efektif perusahaan menggunakan ekuitasnya, dan akhirnya kepercayaan investor atas modal yang di investasikannya terhadap perusahaan lebih baik serta dapat memberi pengaruh positif bagi harga sahamnya di pasar (Nurfadillah, 2011).

Pembahasan Pengaruh Kualitas Pengungkapan CSR terhadap Harga Saham. Hasil pengujian menyatakan bahwa variabel kualitas pengungkapan CSR tidak berpengaruh terhadap harga saham, sehingga H3 ditolak. Penyebab ditolaknya H3 kemungkinan disebabkan oleh pola hubungan antara kualitas pengungkapan CSR dan harga saham, yang berbentuk hubungan tidak langsung. Amah, dkk (2014) mengungkapkan bahwa hubungan antara pengungkapan CSR dengan harga saham dipengaruhi oleh variabel ukuran perusahaan sebagai pemoderasi yang berfungsi untuk

\section{SIMPULAN}

Kesimpulan. Berdasarkan hasil penelitian dapat disimpulkan bahwa, profitabilitas, yang diukur dengan EPS dan ROE berpengaruh positif terhadap harga saham. Sedangkan kualitas pengungkapan CSR tidak berpengaruh terhadap harga saham.

Saran. Saran yang dapat diajukan dari penelitian ini antara lain, bagi investor, variabel profitabilitas masih menjadi prediktor terbaik bagi harga saham. Untuk penelitian selanjutnya dapat menggunakan sampel yang lebih luas, serta dapat memasukkan variabel tata kelola perusahaan (GCG) dalam model.

\section{DAFTAR PUSTAKA}

Amah, Nik, dkk. 2014. Jurnal LPPM VOL. 2 NO. 2 Juli 2014. 1FPIPS IKIP PGRI Madiun

Alwi Z. Iskandar. (2003). Pasar Modal Teori dan Aplikasi Edisi Pertama. Jakarta:

Yayasan Pancur Siwah.

Basalamah, A. S., \& Jermias, J. (2005). Social and Environmental Reporting and Auditing in Indonesia. Gadjah Mada International Journal of Business, 7(1), 109-127.

Brigham \& Houston. (2009). Dasar-dasar Manajemen Keuangan Edisi Kesepuluh. Jakarta: Salemba Empat.

De Klerk, M., C. De Villiers, dan C.Van Staden. 2015. "The Influence of Corporate Social Responsibility Disclosure on Share Price". Pacific Accounting Review, Vol. 27 Iss 2 pp. 208-228. Diakses tanggal 9 September 2015, dari Emerald Insight.

Fauzi, Muhamad, Metode Penilitian Kuantitatif (sebuah pengantar), Semarang: Walisongo press, 2009.

F Brigham, E. \& Houston, joel F., 2004. DasarDasar Manajemen Keungan. Buku 1 Edisi 10., Jakarta: Salemba Empat.

Ghozali, I., 2013. Aplikasi Analisis Multivariate dengan Program IBM SPSS 21, Semarang: Universitas Diponegoro.

Ghozali, I. \& Chariri, A., 2014. Teori Akuntansi 4th ed., Semarang: Universitas Diponegoro.

Gray, R., Kouhy, R. \& Lavers, S., 1995. Corporate social and environmental reporting: a review of thelnliterature and a longitudinal study of UK disclosure. Accounting, Auditing \& Accountability Journal, 8(2), pp.47-77. 
Hidayansyah, Putri Fika, dkk. 2015. Pengaruh Pengungkapan Corporate Social Responsibility Terhadap Kinerja Keuangan dan Harga Saham pada Sektor Properti di Bursa Efek Indonesia Jurnal Manajemen dan Organisasi Vol VI, No 1, April 2015. Institut Pertanian Bogor

Indriantoro, N. \& Supomo, B., 1999. Metodologi Penelitian Bisnis: Untuk Akuntansi \& Manajemen edisi pert., Yogyakarta: PT BPFE.

Kuncoro, M., 2004. metode kuantitatif "Teori dan Aplikasi untuk Bisnis dan Ekonomi edisi ke 2., Yogyakarta: AMP YKPN.

Kusumadilaga, Rimba. 2010. "Pengaruh Corporate Social Rresponsibility Terhadap Nilai Perusahaan Dengan Profitabilitas Sebagai Variabel Moderating". Tesis S-2 : Universitas Diponegoro Semarang. http://www.enprints. undip.ac.id.

Kasmir. (2012). Analisis Laporan Keuangan. Jakarta : PT Raja Grafindo Persada

Lako, A., 2011. Dekonstruksi CSR dan Reformasi Paradigma Bisnis dan Akuntansi, Jakarta: Erlangga.

Laskar, N. \& Gopal Maji, S., 2016. Corporate Sustainability Reporting practices in India/ : Myth or Reality/ ? Social Responsibility Journal, 12(4).

Martono dan Agus Harjito. (2005). Manajemen Keuangan. Yogyakarta: Ekonosia.

Moeljadi, 2006, Manajemen Keuangan Pendekatan Kuantitatif dan Kualitatif, BPFE: Yogyakarta.

Muammarsyah. (2012). Pengaruh Return On Asset, Return On Equity, Earnings Per Share, Laba Unexpected Dan Ukuran Perusahaan Terhadap Return Saham Pada Perusahaan Manufaktur yang Terdaftar Di Bursa Efek Indonesia, Fakultas Ekonomi, Universitas Sumatera Utara. 2303-2553, 72-85.

Mukhtaruddin. 2007. "Pengaruh Return On Asset
(ROA), Return On Equity (ROE), Return On Investment, Debt to Equity Ratio (DER), dan Book Value (BV) Terhadap Harga Saham Property di BEI". Jurnal Penelitian dan Pengembangan Akuntansi

Murhadi, Werner R. 2013. Analisis Laporan Keuangan, Proyeksi dan Valuasi. Saham. Jakarta: Salemba Empat.

Nurfadillah, Mursidah. 2011. Analisis Pengaruh Earning Per Share, Debt to Equity Ratio, dan Return On Equity terhadap Harga Saham $P T$. Unilever Indonesia tbk. Jurnal Manajement \& Akuntansi Vol. 12, No. 1, April 2011. STIE Muhammadiyah Sanarinda

Sartono, R.A., 2012. Manajemen Keuangan. Teori dan Aplikasi edisi ke 4., Yogyakarta: BPFE.

Sekaran, U., 2006. Metodologi Penelitian untuk Bisnis Pertama., Jakarta: Salemba Empat.

Sembiring, Eddy Rismanda. (2003). Kinerja Keuangan, Political Visibility, Ketergantungan pada Hutang, dan Pengungkapan Tanggung Jawab Sosial Perusahaan.Simposium Nasional Akuntansi 6

Sugiyono, 2008. Metode Penelitian Bisnis, Bandung: ALVABETA.

Sugiarto. 2009. Struktur Modal, Struktur Kepemilikan Perusahaan, Permasalahan Keagenan dan Informasi Asimetri. Edisi Pertama. Yogyakarta : Graha Ilmu

Susana. (2007). “Analisis Reaksi Pasar Terhadap Lumpur Lapindo (Studi Kasus Harga Saham dan Volume Perdagangan Saham pada Perusahaan yang Terdaftar di Bursa Efek Jakarta)". Skripsi: Universitas Islam Negeri Sunan Kalijaga Yogyakarta.

Tandelilin, E. 2001. Analisis Investasi dan Manajemen Portofolio. Yogyakarta:BPFE

Weston, J. Fred dan Brigham, Eugene F. (2001). Dasar-dasar Manajemen Keuangan. Jakarta: Erlangga. 